Check for updates

Cite this: RSC Adv., 2017, 7, 55296

Received 9th October 2017

Accepted 29th November 2017

DOI: $10.1039 / c 7 r a 11086 c$

rsc.li/rsc-advances

\title{
A mitochondria-targeting ratiometric fluorescent probe for the detection of hypochlorite based on the FRET strategy $\uparrow$
}

\author{
Shi-Li Shen, (D)*a Xiao-Fan Zhang, ${ }^{\text {b }}$ Yan-Qing Ge, (D) ${ }^{a}$ Yan Zhu ${ }^{a}$ \\ and Xiao-Qun Cao iD *a
}

In this study, a ratiometric fluorescent probe (IRP) for ${ }^{-} \mathrm{OCl}$ was designed based on the fluorescence resonance energy transfer (FRET) platform. The probe was fabricated by integrating an imidazo[1,5-a] pyridine moiety (donor) with a rhodamine moiety (acceptor). We evaluated its properties for recognizing - $\mathrm{OCl}$ and the results implied that IRP possessed high selectivity, a real-time detection possibility and brilliant photostability. The fluorescence intensity ratios $\left(/_{575} / /_{467}\right)$ of IRP displayed desirable ${ }^{-} \mathrm{OCl}-$ dependent performance and responded linearly to ${ }^{-} \mathrm{OCl}$ in the concentration range of $0.5-3.5 \mu \mathrm{M}$. Also, IRP was applied to image endogenous ${ }^{-} \mathrm{OCl}$ with a mitochondria-targeting ability, due to the introduction of the quaternized pyridine moiety. Therefore, IRP may be used for further mitochondrial -OCl-related studies.

\section{Introduction}

Reactive oxygen species (ROS) are of scientific interest since they could mediate a number of biological processes. Hypochlorous acid $(\mathrm{HOCl}) /$ hypochlorite $\left({ }^{-} \mathrm{OCl}\right)$, one of the most important ROS, has received increasing attention recently. ${ }^{-} \mathrm{OCl}$ is synthesized from hydrogen peroxide and chloride with the aid of myeloperoxidase (MPO) in immunological cells. ${ }^{-}{ }^{-} \mathrm{OCl}$ is a powerful oxidizer with effective antibacterial properties when microorganism infections occur. ${ }^{2}$ Despite that, the abnormal generation of ${ }^{-} \mathrm{OCl}$ in vivo may be harmful and is implicated in various diseases such as rheumatoid arthritis, atherosclerosis, osteoarthritis and lung injury. ${ }^{3-6}$ Thus, scientists have devoted effort to developing sensitive and accurate methods to detect ${ }^{-} \mathrm{OCl}$. Among the analytical methods, fluorescent probes show many advantages in terms of sensitivity and selectivity as well as spectral resolution. ${ }^{7-18}$ Single emission-based probes are flawed in quantitative assays, because the results may be perturbed by environmental factors. Ratiometric probes, which can normalize the interference, have been a powerful approach for recognizing and detecting ${ }^{-} \mathrm{OCl} .{ }^{19,20}$

Fluorescence resonance energy transfer (FRET) strategy is an effective approach to constructing ratiometric probes.

${ }^{a}$ School of Chemistry and Pharmaceutical Engineering, Taishan Medical University, Taian 271016, P. R. China. E-mail: slshen86@163.com; xiaoquncao@126.com; Fax: +86-538-6229741; Tel: +86-538-6229741

${ }^{b}$ Taian Center for Food and Drug Control, Taian 271000, P. R. China

$\uparrow$ Electronic supplementary information (ESI) available. See DOI: $10.1039 / \mathrm{c} 7 \mathrm{ra11086 \textrm {c }}$
FRET-based probes for ${ }^{-}$OCl display two well-resolved emission peaks before and after reaction with ${ }^{-} \mathrm{OCl}{ }^{21-23}$ However, despite the good performance, it is difficult to construct such an FRET-based system on account of the prerequisite of substantial spectral overlap between donor emission and acceptor absorption. Hence, it is highly desirable to develop novel fluorophores for the fabrication of FRET-based probes.

By far, clarifying the intracellular functions of ${ }^{-} \mathrm{OCl}$ is still a challenge since the subcellular distribution of ${ }^{-} \mathrm{OCl}$ is uncertain. So it is highly urgent to fabricate fluorescent probes for ${ }^{-} \mathrm{OCl}$ possessing organelle-targeting ability. To the best of our knowledge, some organelle-targeting probes for ${ }^{-} \mathrm{OCl}$ have been developed. ${ }^{24-28}$ However, ${ }^{-} \mathrm{OCl}$ ratiometric probes based on FRET that can be applied especially in mitochondria are still in great demand. ${ }^{23,29}$

Previously we designed a ratiometric probe for sensing copper ion based on imidazo[1,5-a]pyridine-rhodamine FRET system. ${ }^{30}$ The data indicated that emission spectrum of imidazo [1,5- $a]$ pyridine and absorption spectrum of rhodamine largely overlapped, thus giving efficient FRET process. Inspired by this, we chose imidazo[1,5- $a$ ]pyridine as FRET donor and rhodamine as FRET acceptor to produce $\mathrm{a}^{-} \mathrm{OCl}$ ratiometric probe (IRP). IRP exhibited high selectivity and sensitivity toward ${ }^{-} \mathrm{OCl}$. In comparison with other ${ }^{-}$OCl probes, probe IRP showed much lower detection limit $(10.2 \mathrm{nM}) \cdot{ }^{31-34}$ Moreover, quaternized pyridine moiety, which was a mitochondria-targeting group, was introduced into the probe to achieve mitochondriatargeting ability. ${ }^{6,23,29}$ IRP has also been applied for fluorescence imaging of endogenous ${ }^{-} \mathrm{OCl}$ with excellent membrane permeability and stability. 


\section{Results and discussion}

\section{Design and synthesis of probe IRP}

The imidazo[1,5- $a]$ pyridine fluorophore was chosen as the FRET donor due to its outstanding spectroscopic properties. ${ }^{35-37}$ And rhodamine moiety was selected as FRET acceptor, because the emission spectra of imidazo[1,5- $a]$ pyridine and the excitation spectra of rhodamine largely overlapped, which was essential for an efficient energy transfer process. Importantly, the quaternized pyridine moiety was introduced into probe IRP to realize the mitochondria-targeting capability. We expected that the quaternized pyridine moiety in probe IRP would enable the probe to be suitable for the fluorescence imaging of endogenous ${ }^{-} \mathrm{OCl}$ in mitochondria.

Probe IRP was synthesized via a simple process (Scheme 1) and characterized by ${ }^{1} \mathrm{H}$ NMR, ${ }^{13} \mathrm{C}$ NMR and HRMS (Fig. S1-S3, $\mathrm{ESI} \dagger$ ).

\section{Spectroscopic response of probe IRP to ${ }^{-}$OCl}

The absorption spectra of IRP were investigated in EtOH-PBS (3/ 7, v/v, pH 7.4). As shown in Fig. 1, IRP exhibited a maximal absorption band at $365 \mathrm{~nm}$, which was assigned to the imidazo $[1,5-a]$ pyridine moiety. And the absorbance was almost unchanged along with ${ }^{-} \mathrm{OCl}$ addition. Upon addition of ${ }^{-} \mathrm{OCl}$, a new absorption peak appeared at $555 \mathrm{~nm}$ and the absorbance increased remarkably. The spectra changes could be attributed to the structural formation of ring-opened form of rhodamine moiety, induced by the reaction of IRP and ${ }^{-} \mathrm{OCl}$.

To explore the fluorescence response of IRP to ${ }^{-} \mathrm{OCl}$, probe IRP was titrated with various concentrations of ${ }^{-} \mathrm{OCl}$ (Fig. 2a). Upon excitation at $370 \mathrm{~nm}$, the probe only emitted the fluorescence of imidazo[1,5- $a]$ pyridine moiety $(467 \mathrm{~nm})$. When ${ }^{-} \mathrm{OCl}$ was titrated from 0 to $5 \mu \mathrm{M}$, the emission peak of imidazo[1,5- $a$ ] pyridine decreased. Meanwhile, a typical emission peak of rhodamine moiety emerged at $575 \mathrm{~nm}$ and the fluorescence intensity increased gradually, which was in perfect agreement with the absorption spectra changes. The phenomena could be ascribed to the energy transfer between imidazo[1,5- $a]$ pyridine donor and rhodamine acceptor (Scheme 2). The rhodamine moiety was in the ring-closed form in the absence of ${ }^{-} \mathrm{OCl}$, and no FRET was found in probe IRP at this stage. However, the titration of ${ }^{-} \mathrm{OCl}$ resulted in the rhodamine structural transformation from spirolactam form (non-fluorescent) to ringopened form (fluorescent). The HRMS spectra of the reaction

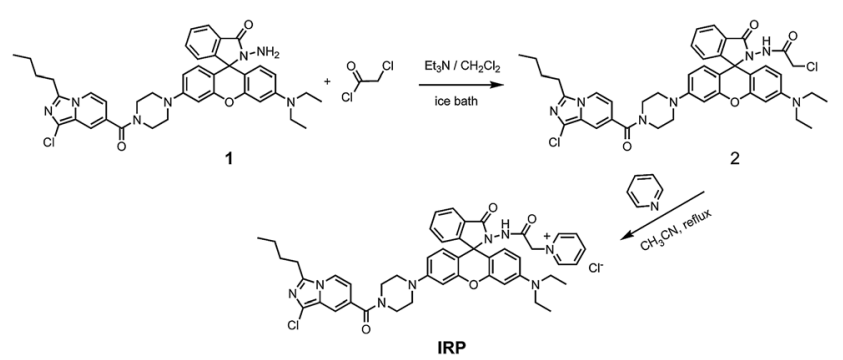

Scheme 1 Synthesis of probe IRP.

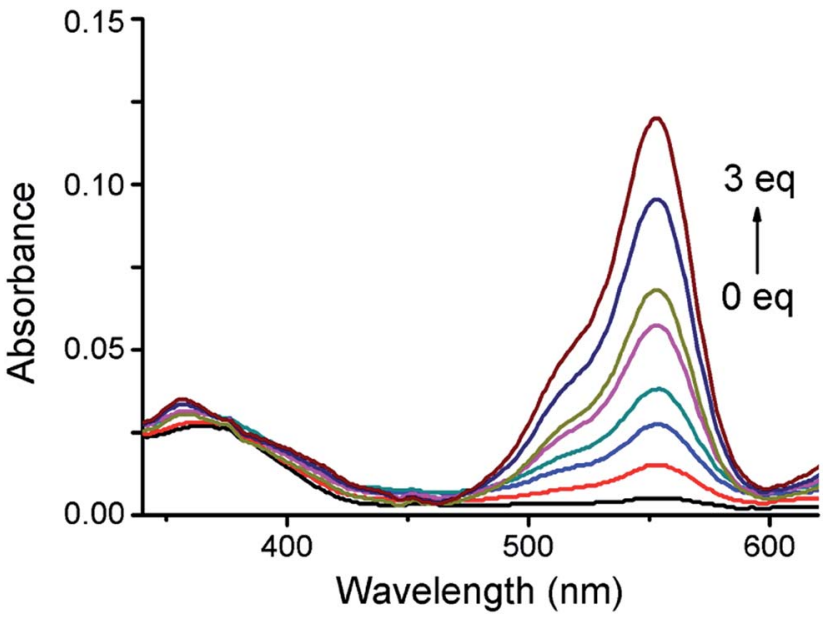

Fig. 1 Absorption spectra of probe IRP $(5 \mu \mathrm{M})$ upon addition of ${ }^{-} \mathrm{OCl}$.

mixture of IRP with ${ }^{-}$OCl (Fig. S4 $\dagger$ ) verified the structure change of rhodamine moiety. And the ring-opened rhodamine moiety was an efficient energy acceptor. FRET process between imidazo [1,5-a]pyridine donor and rhodamine acceptor occurred accordingly. The energy transfer efficiency was determined to be $45 \%$.

Fluorescence intensity ratios $\left(I_{575} / I_{467}\right)$ as a function of ${ }^{-} \mathrm{OCl}$ concentration were illustrated in Fig. 2b. When the ${ }^{-} \mathrm{OCl}$ concentration increased from 0 to $5 \mu \mathrm{M}, I_{575} / I_{467}$ exhibited a significant enhancement. More importantly, the inset indicated that there was a linear correlation between the fluorescence intensity ratio $\left(I_{575} / I_{467}\right)$ and the ${ }^{-} \mathrm{OCl}$ concentration from 0.5 to $3.5 \mu \mathrm{M}(R=0.998)$. In addition, the limit of detection was calculated to be $10.2 \mathrm{nM}$, which demonstrated that probe IRP may be able to monitor ${ }^{-}$OCl changes at trace levels.

In order to investigate whether the probe could selectively respond to ${ }^{-} \mathrm{OCl}$, we evaluated the influence of potential interferents, including ROS/RNS and common ions. As shown in Fig. 3, compared to other tested analytes, only the presence of OCl caused a dramatic increase of $I_{575} / I_{467}$ for the probe IRP. The results indicated that the probe possessed excellent selectivity for ${ }^{-} \mathrm{OCl}$ even in the complicated intracellular environment.

The effect of solution $\mathrm{pH}$ on the fluorescence response of IRP toward ${ }^{-}$OCl was also studied (Fig. 4). Probe IRP itself was stable
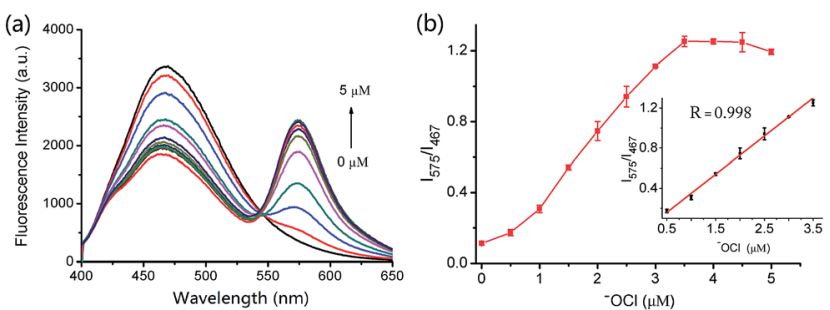

Fig. 2 (a) Fluorescence titration spectra and (b) fluorescence intensity ratios $\left(/_{575} / /_{467}\right)$ of probe IRP $(2 \mu \mathrm{M})$ upon addition of ${ }^{-} \mathrm{OCl}$. The inset showed the linear relationship of intensity ratios $\left(/_{575} / /_{467}\right)$ along with OCl concentration ( $R=0.998$ ). 

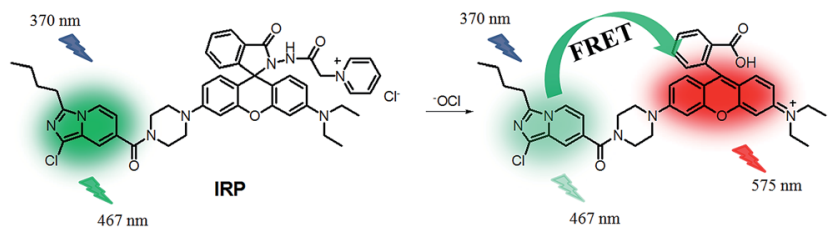

Scheme 2 Proposed mechanism of IRP for sensing ${ }^{-} \mathrm{OCl}$.

in the $\mathrm{pH}$ range of 4.0-10.0. After ${ }^{-} \mathrm{OCl}(2 \mu \mathrm{M})$ was added to the IRP solution, the fluorescence intensity ratio $\left(I_{575} / I_{467}\right)$ increased notably and peaked at $\mathrm{pH}$ 7.4, implying that IRP could be used to detect ${ }^{-} \mathrm{OCl}$ in neutral and slightly basic conditions. Since the $\mathrm{p} K_{\mathrm{a}}$ of $\mathrm{HOCl}$ was 7.6, we speculated that the probe could sense ${ }^{-} \mathrm{OCl}$ rather than $\mathrm{HOCl}$. In consideration of the weakly basic $\mathrm{pH}$ conditions in mitochondria, we anticipated that IRP may be suitable for mitochondrial ${ }^{-} \mathrm{OCl}$ measurement.

Furthermore, the time courses of IRP were recorded upon addition of ${ }^{-} \mathrm{OCl}(3 \mu \mathrm{M})$. As displayed in Fig. S5, $\uparrow$ the fluorescence intensity ratios $\left(I_{575} / I_{467}\right)$ of IRP instantly increased and reached a plateau after ${ }^{-} \mathrm{OCl}$ was added to the solution. Hence, the probe was able to sense ${ }^{-} \mathrm{OCl}$ rapidly, which was pivotal for the real-time detection of ${ }^{-} \mathrm{OCl}$. The high specificity of IRP for -OCl over other species, fast response, as well as the satisfactory - OCl-dependent performance further confirmed that probe IRP had great potential as a practical tool for ${ }^{-} \mathrm{OCl}$ detection in vivo.

\section{Cell imaging of probe IRP}

In light of the excellent spectroscopic response of probe IRP toward ${ }^{-} \mathrm{OCl}$ in vitro, we proceeded to explore the biological application of cell imaging. Murine RAW264.7 cells were selected to image endogenous $\mathrm{HOCl}$ in living cells, since RAW264.7 cells would produce $\mathrm{HOCl}$ after the stimulation with lipopolysaccharide (LPS). ${ }^{23}$ After RAW264.7 cells were incubated with IRP $(1 \mu \mathrm{M})$

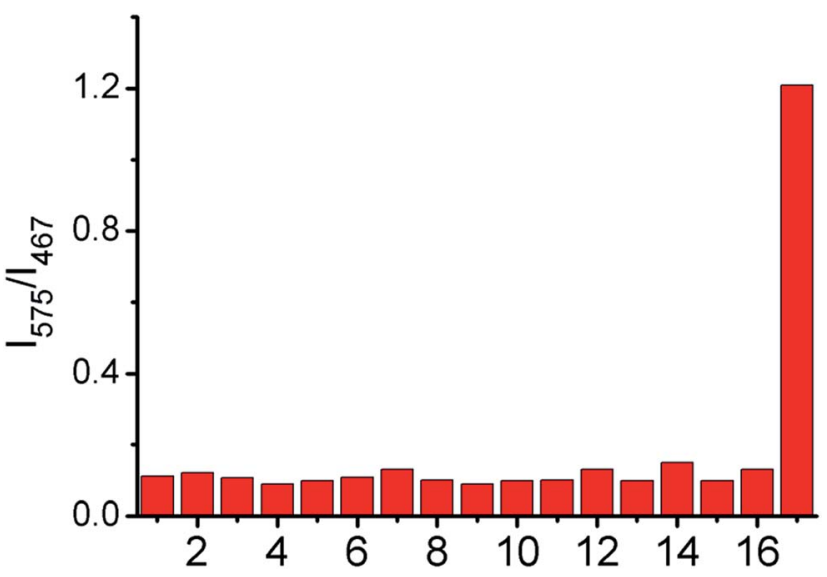

Fig. 3 Fluorescence intensity ratios $\left(/_{575} / /_{467}\right)$ of probe IRP $(2 \mu \mathrm{M})$ containing other ROS/RNS, ions and ${ }^{-} \mathrm{OCl}$. (1): blank, (2): $\mathrm{H}_{2} \mathrm{O}_{2},(3)$ : $t$ $\mathrm{BuOOH},(4): t-\mathrm{BuO}^{\circ},(5):{ }^{1} \mathrm{O}_{2},(6):{ }^{-} \mathrm{O}_{2},(7): \mathrm{ON}_{1}(8):{ }^{\circ} \mathrm{OH},(9): \mathrm{ONOO}^{-}$, (10): $\mathrm{NO}_{2}^{-},(11): \mathrm{AcO}^{-},(12): \mathrm{Br}^{-},(13): \mathrm{Cl}^{-},(14): \mathrm{I}^{-},(15): \mathrm{CO}_{3}^{2-},(16):$ $\mathrm{SO}_{4}{ }^{2-}$, (17): ${ }^{-} \mathrm{OCl}$. Concentration: $40 \mu \mathrm{M}$ for (2)-(9); $4 \mu \mathrm{M}$ for (17), $1 \mathrm{mM}$ for others.

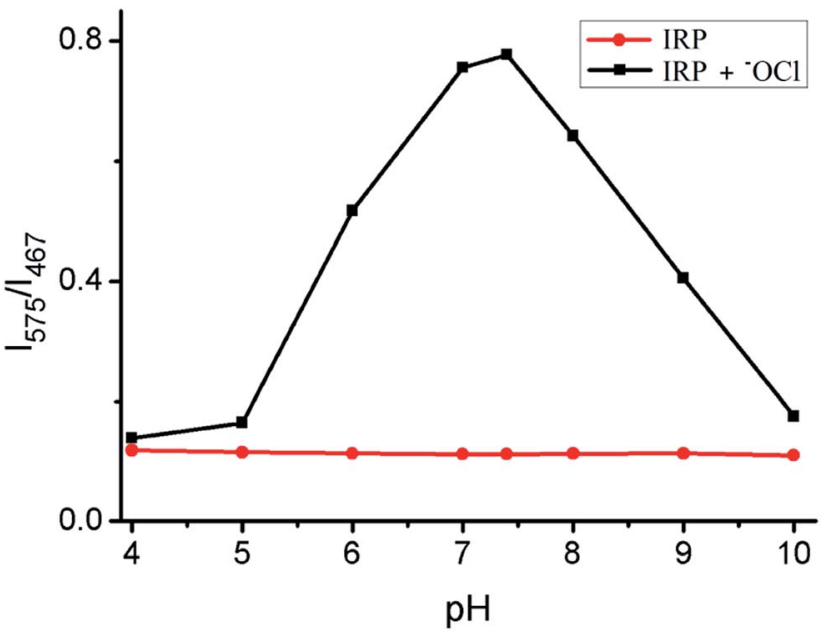

Fig. 4 Fluorescence intensity ratios $\left(/_{575} / /_{467}\right)$ of IRP $(2 \mu \mathrm{M})$ versus $\mathrm{pH}$ in the absence $(\mathbf{)})$ or presence $(\mathbf{\square})$ of ${ }^{-} \mathrm{OCl}(2 \mu \mathrm{M})$.

for $30 \mathrm{~min}$, bright blue fluorescence and weak red fluorescence were noticed, as shown in Fig. 5a. Whereas in the experiment group, RAW264.7 cells were incubated with LPS for $6 \mathrm{~h}$ and then with phorbol 12-myristate 13-acetate (PMA) for $30 \mathrm{~min}$, followed by incubation with probe IRP $(1 \mu \mathrm{M})$ for $30 \mathrm{~min}$. According to the previous papers, the synergistic effect of LPS and PMA could stimulate RAW264.7 cells to produce $\mathrm{HOCl}^{38-41}$ The blue fluorescence turned weaker and the red fluorescence became stronger, compared to the control group without LPS. Moreover, the fluorescence intensity ratio (blue to red) declined obviously in the presence of LPS (Fig. 5b). The results suggested that probe IRP could sense endogenous ${ }^{-} \mathrm{OCl}$ in living cells.

To further determine the subcellular localization of IRP, the commercially available mitochondrial dye, Mito Tracker Deep Red, was utilized for the co-localization study (Fig. 6). RAW264.7 cells were incubated with the probe $(1 \mu \mathrm{M})$ for $30 \mathrm{~min}$ and then with Mito Tracker Deep Red $(0.2 \mu \mathrm{M})$ for $30 \mathrm{~min}$. The imidazo [1,5-a]pyridine signals in IRP-loaded cells overlapped significantly with the signals of Mito Tracker Deep Red (Fig. 6c) and the co-localization coefficient was calculated to be 0.95 . The
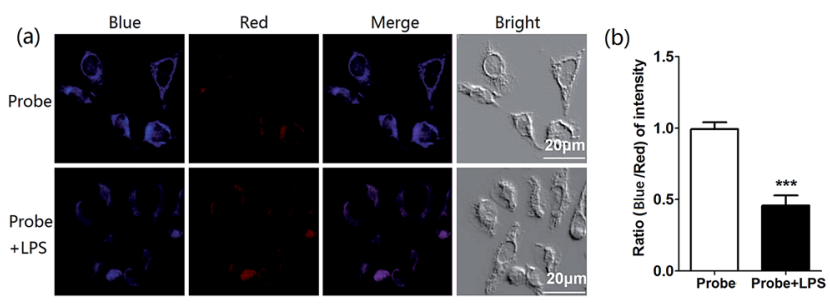

Fig. 5 (a) Fluorescence images of RAW264.7 cells. First line: the cells incubated with IRP $(1 \mu \mathrm{M})$ for $30 \mathrm{~min}$, second line: the cells treated with LPS $\left(1 \mu \mathrm{g} \mathrm{mL}^{-1}\right)$ for $6 \mathrm{~h}$, then with PMA $\left(1 \mu \mathrm{g} \mathrm{mL}^{-1}\right)$ for $30 \mathrm{~min}$ and with IRP $(1 \mu \mathrm{M})$ for $30 \mathrm{~min}$. First column: imidazo[1,5-a]pyridine fluorescence (410-520 nm), second column: rhodamine fluorescence (560$700 \mathrm{~nm})$, third column: overlap images of the first and second columns, fourth column: bright field images. (b) Fluorescence intensity quantitation was analyzed using the Image J. The results were presented as mean $\pm \mathrm{SE}$ with replicates $n=3$. 

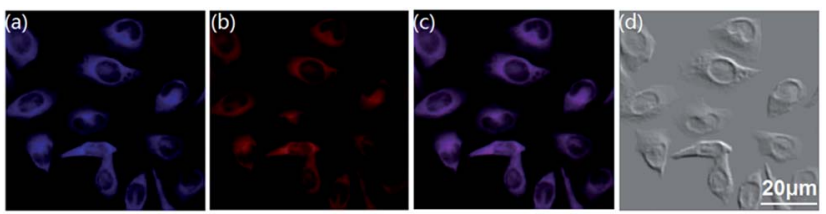

Fig. 6 Fluorescence images of RAW264.7 cells co-stained with IRP (1 $\mu \mathrm{M})$ and Mito Tracker Deep Red $(0.2 \mu \mathrm{M})$. (a) Imidazo[1,5-a]pyridine fluorescence of IRP. (b) Fluorescence of Mito Tracker Deep Red. (c) Overlay of (a) and (b). (d) Bright field images.

results indicated that IRP could selectively stain mitochondria. In addition, we also conducted the co-localization assays of IRP with Lyso Tracker Deep Red. After RAW264.7 cells were incubated with IRP $(1 \mu \mathrm{M})$ for $30 \mathrm{~min}$ and then with Lyso Tracker Deep Red $(0.2 \mu \mathrm{M})$ for $30 \mathrm{~min}$, the cells were imaged. As depicted in Fig. $\mathbf{S 6}, \uparrow$ the probe was not site-specifically internalized in lysosomes (co-localization coefficient: 0.20 ). Therefore, the co-localization data confirmed that probe IRP could target mitochondria.

Considering that a probe's cytotoxicity and photostability were vital parameters for the cellular bio-imaging, so we next evaluated the cytotoxicity of IRP by standard SRB assays. Fig. S7 $\uparrow$ revealed that the cell viability was affected little after incubation with IRP $(1,2,4,6 \mu \mathrm{M})$ for $12 \mathrm{~h}$. Furthermore, the photostablity property of the probe was inspected and the results implied that probe IRP exhibited satisfactory photostablity within $120 \mathrm{~s}$ under the experimental conditions (Fig. S8†).

\section{Experimental}

\section{Apparatus and chemicals}

${ }^{1} \mathrm{H}$ NMR $(400 \mathrm{MHz})$ and ${ }^{13} \mathrm{C}$ NMR $(100 \mathrm{MHz})$ spectra were acquired on a Bruker Avance spectrometer, with $d_{6}$-DMSO used as a solvent and tetramethylsilane (TMS) as an internal standard. High-resolution mass spectroscopy (HRMS) was collected on a Q-TOF6510 spectrograph (Agilent). UV-vis spectra were measured by a Hitachi U-4100 spectrophotometer. Fluorescent measurements were performed on a Perkin-Elmer LS-55 luminescence spectrophotometer. The $\mathrm{pH}$ was determined with a model PHS-3C pH meter (YouKe, Shanghai, China).

-OCl solution was prepared by diluting the commercially available NaOCl solution. ROS and reactive nitrogen species (RNS) solutions were prepared by the literature. ${ }^{42-44}$ Unless otherwise stated, all reagents were used without further purification from merchants. Twice-distilled water was used throughout all experiments.

\section{Preparation of test solutions}

Probe IRP was dissolved in ethanol to afford the stock solution $\left(10^{-4} \mathrm{M}\right)$. All analysis samples were prepared by displacing the stock solution into a $10 \mathrm{~mL}$ volumetric flask. The solution was diluted to $10 \mathrm{~mL}$ in a mixture solution of EtOH-PBS (pH 7.4) = $3: 7, \mathrm{v} / \mathrm{v}$. Appropriate aliquots of each testing species solution were then added. The resulting solutions were shaken well and incubated for $30 \mathrm{~min}$ before measurements.

\section{Synthesis of probe IRP}

The synthetic route of probe IRP was displayed in Scheme 1, in which compound 1 was prepared according to our previous work. ${ }^{30}$ Compound 1 (1.0 mmol $)$ was dissolved in dry dichloromethane $(20 \mathrm{~mL})$ and triethylamine $(3.3 \mathrm{mmol})$. The solution was cooled to $0{ }^{\circ} \mathrm{C}$ with stirring under nitrogen atmosphere. Then, chloroacetyl chloride $(3.0 \mathrm{mmol})$ was added dropwise to the solution. After addition, the reaction was stirred at $0{ }^{\circ} \mathrm{C}$ for $4 \mathrm{~h}$. Subsequently, the solvent was removed under reduced pressure to give compound 2 . The crude product was used for next step without purification.

Compound $2(1.0 \mathrm{mmol})$ and pyridine $(1 \mathrm{~mL})$ were dissolved in anhydrous acetonitrile $(30 \mathrm{~mL})$. The solution was refluxed overnight. Then the solvent was removed under reduced pressure and the crude product was purified by column chromatography on silica gel using dichloromethane/methanol (10/1, v/ $\mathrm{v}$ ) as the eluent to obtain IRP as a faint yellow solid (yield: 49.6\%). ${ }^{1} \mathrm{H}$ NMR (400 MHz, $d_{6}$-DMSO), $\delta$ (ppm): 0.92 (t, $3 \mathrm{H}, J=$ $\left.7.6 \mathrm{~Hz}, \mathrm{CH}_{3}\right), 1.09\left(\mathrm{t}, 6 \mathrm{H}, J=6.8 \mathrm{~Hz}, \mathrm{CH}_{3}\right), 1.32(\mathrm{q}, 2 \mathrm{H}, J=7.6 \mathrm{~Hz}$, $\left.\mathrm{CH}_{2}\right), 1.68-1.73\left(\mathrm{~m}, 2 \mathrm{H}, \mathrm{CH}_{2}\right), 2.92\left(\mathrm{t}, 2 \mathrm{H}, J=7.4 \mathrm{~Hz}, \mathrm{CH}_{2}\right), 3.26$ (br, $\left.4 \mathrm{H}, \mathrm{CH}_{2}\right), 3.32\left(\mathrm{br}, 4 \mathrm{H}, \mathrm{CH}_{2}\right), 3.68\left(\mathrm{br}, 4 \mathrm{H}, \mathrm{CH}_{2}\right), 5.48(\mathrm{~s}, 2 \mathrm{H}$, $\left.\mathrm{CH}_{2}\right), 6.34(\mathrm{~d}, 2 \mathrm{H}, J=9.2 \mathrm{~Hz}, \mathrm{ArH}), 6.49(\mathrm{~d}, 1 \mathrm{H}, J=8.8 \mathrm{~Hz}, \mathrm{ArH})$, 6.56-6.61 (m, 2H, ArH), $6.68(\mathrm{~d}, 1 \mathrm{H}, J=2.0 \mathrm{~Hz}, \mathrm{ArH}), 6.75(\mathrm{~d}, 1 \mathrm{H}$, $J=7.2 \mathrm{~Hz}, \mathrm{ArH}), 7.05(\mathrm{~d}, 1 \mathrm{H}, J=6.8 \mathrm{~Hz}, \mathrm{ArH}), 7.52(\mathrm{~s}, 1 \mathrm{H}, \mathrm{ArH})$, 7.54-7.62 (m, 2H, ArH), $7.85(\mathrm{~d}, 1 \mathrm{H}, J=6.8 \mathrm{~Hz}, \mathrm{ArH}), 8.14-8.17$ $(\mathrm{m}, 2 \mathrm{H}, \mathrm{ArH}), 8.29(\mathrm{~d}, 1 \mathrm{H}, J=7.2 \mathrm{~Hz}, \mathrm{ArH}), 8.70(\mathrm{t}, 1 \mathrm{H}, J=$ $8.0 \mathrm{~Hz}, \mathrm{ArH}), 8.74(\mathrm{~d}, 2 \mathrm{H}, J=5.6 \mathrm{~Hz}, \mathrm{ArH}), 10.60(\mathrm{~s}, 1 \mathrm{H}, \mathrm{NH}) .{ }^{13} \mathrm{C}$ NMR (100 MHz, $d_{6}$-DMSO), $\delta$ (ppm): 167.6, 164.2, 163.8, 153.4, 153.1, 151.8, 151.7, 149.0, 146.9, 146.1, 138.9, 134.1, 129.5, $129.4,129.2,128.5,128.2,126.4,124.3,123.7,123.3,122.8$, 118.7, 115.9, 112.4, 111.7, 108.5, 108.4, 104.1, 101.9, 97.5, 65.5, 60.6, 47.9, 44.1, 29.4, 29.1, 25.6, 22.1, 14.1, 12.9. HRMS $\mathrm{m} / \mathrm{z}$ : calcd for $\mathrm{C}_{47} \mathrm{H}_{48} \mathrm{ClN}_{8} \mathrm{O}_{4} \mathrm{~S}[\mathrm{M}]^{+}$: 823.3487; found: 823.3552. $\mathrm{m} / \mathrm{z}$ : calcd for $\mathrm{C}_{47} \mathrm{H}_{49} \mathrm{ClN}_{8} \mathrm{O}_{4} \mathrm{~S}[\mathrm{M}+\mathrm{H}]^{2+} / 2: 412.1782$; found: 412.1790 .

\section{Cell culture and imaging}

RAW264.7 cells (ATCC $®$ TIB-71 ${ }^{\mathrm{TM}}$ ) were cultured in Dulbecco's modified Eagle's medium (DMEM) supplemented with $10 \%$ (v/ v) fetal bovine serum in an atmosphere containing $5 \% \mathrm{CO}_{2}$ and $95 \%$ air at $37{ }^{\circ} \mathrm{C}$. The cells were imaged using confocal fluorescence microscopy (Leica SP8).

\section{Conclusion}

In summary, we employed imidazo[1,5-a]pyridine-rhodamine FRET platform to develop a ratiometric fluorescent probe for OCl. The probe was able to detect ${ }^{-} \mathrm{OCl}$ selectively and function well in mitochondrial physiological $\mathrm{pH}$ conditions. $I_{575} / I_{467}$ ratios of the probe responded linearly to minor fluctuations of OCl concentration $(0.5-3.5 \mu \mathrm{M})$. Moreover, the probe was applied to sense endogenous ${ }^{-} \mathrm{OCl}$ in RAW264.7 cells with negligible toxicity. In particular, the probe could target mitochondria due to the introduction of the quaternized pyridine moiety. Hence, we expected that the probe would be a promising candidate for highly selective and sensitive sensing of OCl in mitochondria. 


\section{Conflicts of interest}

There are no conflicts to declare.

\section{Acknowledgements}

This study was supported by the Natural Science Foundation of Shandong Province (ZR2016BB35), Foundation of Taishan Medical University (2016GCC08), National Natural Science Foundation of China (21602153 and 11574009).

\section{Notes and references}

1 J. E. Harrison and J. Schultz, J. Biol. Chem., 1976, 251, 13711374.

2 Z. M. Prokopowicz, F. Arce, R. Biedron, C. L. Chiang, M. Ciszek, D. R. Katz, M. Nowakowska, S. Zapotoczny, J. Marcinkiewicz and B. M. Chain, J. Immunol., 2010, 184, 824-835.

3 E. Hidalgo, R. Bartolome and C. Dominguez, Chem.-Biol. Interact., 2002, 139, 265-282.

4 A. Daugherty, J. L. Dunn, D. L. Rateri and J. W. Heinecke, J. Clin. Invest., 1994, 94, 437-444.

5 S. M. Wu and S. V. Pizzo, Arch. Biochem. Biophys., 2001, 391, 119-126.

6 J. T. Hou, M. Y. Wu, K. Li, J. Yang, K. K. Yu, Y. M. Xie and X. Q. Yu, Chem. Commun., 2014, 50, 8640-8643.

7 K. M. Xiong, F. J. Huo, C. X. Yin, Y. Y. Chu, Y. T. Yang, J. B. Chao and A. M. Zheng, Sens. Actuators, B, 2016, 224, 307-314.

8 S. M. Chen, J. X. Lu, C. D. Sun and H. M. Ma, Analyst, 2010, 135, 577-582.

9 Z. Yang, M. J. Wang, M. Y. She, B. Yin, Y. Y. Huang, P. Liu, J. L. Li and S. Y. Zhang, Sens. Actuators, B, 2014, 202, 656-662.

10 L. Yuan, W. Y. Lin and H. Chen, Biomaterials, 2013, 34, 95669571.

11 H. Zhu, J. L. Fan, J. Y. Wang, H. Y. Mu and X. J. Peng, J. Am. Chem. Soc., 2014, 136, 12820-12823.

12 J. L. Fan, H. Y. Mu, H. Zhu, J. Y. Wang and X. J. Peng, Analyst, 2015, 140, 4594-4598.

13 Q. A. Best, N. Sattenapally, D. J. Dyer, C. N. Scott and M. E. McCarroll, J. Am. Chem. Soc., 2013, 135, 13365-13370.

14 S. Goswami, S. Paul and A. Manna, Dalton Trans., 2013, 42, 10097-10101.

15 S. Goswami, A. K. Das, A. Manna, A. K. Maity, P. Saha, C. K. Quah, H. K. Fun and H. A. Abdel-Aziz, Anal. Chem., 2014, 86, 6315-6322.

16 S. Goswami, A. Manna, S. Paul, C. K. Quah and H. K. Fun, Chem. Commun., 2013, 49, 11656-11658.

17 A. Manna and S. Goswami, New J. Chem., 2015, 39, 44244429.

18 A. Manna, D. Sarkar, S. Goswami, C. K. Quah and H. K. Fun, RSC Adv., 2016, 6, 57417-57423.

19 S. L. Shen, J. Y. Ning, X. F. Zhang, J. Y. Miao and B. X. Zhao, Sens. Actuators, B, 2017, 244, 907-913.

20 M. G. Ren, B. B. Deng, K. Zhou, X. Q. Kong, J. Y. Wang, G. P. Xu and W. Y. Lin, J. Mater. Chem. B, 2016, 4, 4739-4745.
21 Y. R. Zhang, X. P. Chen, J. Shao, J. Y. Zhang, Q. Yuan, J. Y. Miao and B. X. Zhao, Chem. Commun., 2014, 50, 14241-14244.

22 G. W. Chen, F. L. Song, J. Y. Wang, Z. G. Yang, S. G. Sun, J. L. Fan, X. X. Qiang, X. Wang, B. R. Dou and X. J. Peng, Chem. Commun., 2012, 48, 2949-2951.

23 S. L. Shen, X. Zhao, X. F. Zhang, X. L. Liu, H. Wang, Y. Y. Dai, J. Y. Miao and B. X. Zhao, J. Mater. Chem. B, 2017, 5, 289-295.

24 D. X. Li, Y. Feng, J. Z. Lin, M. Chen, S. X. Wang, X. Wang, H. T. Sheng, Z. L. Shao, M. Z. Zhu and X. M. Meng, Sens. Actuators, B, 2016, 222, 483-491.

25 Z. Xu and L. Xu, Chem. Commun., 2016, 52, 1094-1119.

26 L. Yuan, L. Wang, B. K. Agrawalla, S. J. Park, H. Zhu, B. Sivaraman, J. J. Peng, Q. H. Xu and Y. T. Chang, J. Am. Chem. Soc., 2015, 137, 5930-5938.

27 W. Xu, Z. B. Zeng, J. H. Jiang, Y. T. Chang and L. Yuan, Angew. Chem., Int. Ed., 2016, 55, 13658-13699.

28 H. D. Xiao, K. Xin, H. F. Dou, G. Yin, Y. W. Quan and R. R. Wang, Chem. Commun., 2015, 51, 1442-1445.

29 J. T. Hou, K. Li, J. Yang, K. K. Yu, Y. X. Liao, Y. Z. Ran, Y. H. Liu, X. D. Zhou and X. Q. Yu, Chem. Commun., 2015, 51, 6781-6784.

30 Y. Q. Ge, R. X. Ji, S. L. Shen, X. Q. Cao and F. Y. Li, Sens. Actuators, B, 2017, 245, 875-881.

31 S. L. Shen, X. F. Zhang, Y. Q. Ge, Y. Zhu and X. Q. Cao, Sens. Actuators, B, 2018, 254, 736-741.

32 H. Ma, B. Song, Y. X. Wang, C. L. Liu, X. Wang and J. L. Yuan, Dyes Pigm., 2017, 140, 407-416.

33 Z. Zhang, J. L. Fan, G. H. Cheng, S. Ghazali, J. J. Du and X. J. Peng, Sens. Actuators, B, 2017, 246, 293-299.

34 J. Kang, F. J. Huo, Y. K. Yue, Y. Wen, J. B. Chao, Y. B. Zhang and C. X. Yin, Dyes Pigm., 2017, 136, 852-858.

35 G. J. Song, S. Y. Bai, X. Dai, X. Q. Cao and B. X. Zhao, RSC Adv., 2016, 6, 41317-41322.

36 X. Zhang, G. J. Song, X. J. Cao, J. T. Liu, M. Y. Chen, X. Q. Cao and B. X. Zhao, RSC Adv., 2015, 5, 89827-89832.

37 Y. Q. Ge, X. J. Xing, A. K. Liu, R. X. Ji, S. L. Shen and X. Q. Cao, Dyes Pigm., 2017, 146, 136-142.

38 Q. L. Xu, C. H. Heo, J. A. Kim, H. S. Lee, Y. Hu, D. Y. Kim, K. M. K. Swamy, G. Kim, S. J. Nam, H. M. Kim and J. Y. Yoon, Anal. Chem., 2016, 88, 6615-6620.

39 X. Z. Wang, L. Zhou, F. Qiang, F. Y. Wang, R. Wang and C. C. Zhao, Anal. Chim. Acta, 2016, 911, 114-120.

40 S. V. Mulay, M. Choi, Y. J. Jang, Y. Kim, S. Jon and D. G. Churchill, Chem.-Eur. J., 2016, 22, 9642-9648.

41 G. H. Cheng, J. L. Fan, W. Sun, J. F. Cao, C. Hu and X. J. Peng, Chem. Commun., 2014, 50, 1018-1020.

42 W. L. Wu, Z. M. Zhao, X. Dai, L. Su and B. X. Zhao, Sens. Actuators, B, 2016, 232, 390-395.

43 X. H. Li, G. X. Zhang, H. M. Ma, D. Q. Zhang, J. Li and D. B. Zhu, J. Am. Chem. Soc., 2004, 126, 11543-11548.

44 Z. Ma, W. Sun, L. Z. Chen, J. Li, Z. Z. Liu, H. X. Bai, M. Y. Zhu, L. P. Du, X. D. Shi and M. Y. Li, Chem. Commun., 2013, 49, 6295-6297. 